Oleksandr Deineko, Ukrainian-American Concordia University (Kyiv, Ukraine)

\title{
INFLUENCE OF BILATERAL AND MULTILATERAL TRADE AGREEMENTS ON THE STATE REGULATION OF ECONOMY
}

\begin{abstract}
Interconnection of the state regulation of economy, multilateral trade agreements of global and reginal level, as well as of bilateral agreements, is studied in this paper. Essence and impact of integrative economic processes, which develop through the aforementioned agreements, on tariff and non-tariff regulative instruments is analysed. Dynamics of integrative economic processes at different geographical levels are highlighted. General trends in additional integrative processes within the framework of the WTO and in the outcomes of such are explored in detail.
\end{abstract}

Keywords: international trade, state regulation, barriers to trade, globalisation, integration

International trade relations currently constitutes an objectively needed resource for any kind of effective economic development, becoming an intrinsic element of the expanded economic reproduction of any nation. As time goes by, its influence on production, exchange and distribution tends only to increase; in many counties the international trade is what determines the whole state of the national economies, and this tendency will only become stronger in the future.

Evolution of international trade relations coincides with the evolution of state regulation of economy of such relations. As international trade contains and interconnects not only the interests of different social groups, people and enterprises, but the whole countries too, a state inevitably becomes one of the key regulative subjects in this sphere.

It is hard to overestimate the meaning of the state regulation for creating a sustainable and effective national economy. While always sharing the same abovementioned general goals, its priorities and instruments of choice have shifted over time - from non-interference in the business of the "invisible hand" to the strict regulation of monopolisation processes and stimulation of small enterprises; from closing borders to protect the domestic producers and benefiting from the absolute advantages, to opening them, so to benefit from comparative advantages. In the context of the globalisation and the substantial increase in the part that the foreign trade plays in the development of national economics, tariff and non-tariff instruments of state regulation of economy come to hold one of the most prominent places in these priorities, and they 
are obliged to function in the world where great efforts are undertaken both globally and regionally to lower the trade barriers among the countries and, thus - to economically integrate them.

Generally, as the analytical and scientific sources demonstrate, such integrative processes that increase the freedom of trade between the countries or economic blocks, facilitate economic growth of the participants. For example, for the agri-food markets of almost every country that has signed an integrative agreement with the European Union, several consistent trends may be observed, independently from their geographical locations, development levels or time of entering the abovementioned integrative agreements. First of all, direct foreign investments experience an increase in volume and growth rates; second of all - internal production potential is mobilised, increasing the manufacturing efficiency of the domestic producers; third of all, increase in the production of the products and services with a relatively high added value, thus ensuring a considerable strengthening of the export potential of a given country.

Nevertheless, such integrative processes constitute a double-edged sword. While earlier, separate states had a lot of independence in using tariff and non-tariff instruments for achieving the goals of their policies, with the development of the aforementioned processes and establishment of the World Trade Organisation they became largely limited in executing them, as they constitute the trade barriers that the integrative processes are aimed to overcome. The policies affected particularly include the food security policies and environmental policies, as they are both tightly interconnected with the economic policies.

A good example would be the situation with the production and export of sunflower seeds in Ukraine. The Association Agreement between the European Union and the European Atomic Energy Community and their member states, of the one part, and Ukraine, of the other part that came into force on the 1 st of September of 2017, but has experienced provisional applications earlier, stipulates that the tariff and fiscal encumberment of the sunflower seeds export are to be eliminated, albeit gradually. The thing is, the export encumberments on the sunflower seeds were the key factors that allowed the creation of a strong sunflower oil production, when, in general, the processing sector was in decline after the dissolution of the Soviet Union. As the previous research indicates that governmental deployment of the $23 \%$ export tariff on sunflower seeds in 1999 allowed to transfer the flow of cheap domestic sunflower seeds from external markets to the national processers, ensuring long term positive influence on the trade balance of Ukraine and competitiveness of the Ukrainian sunflower oil in the foreign markets (as seen at the Figure 1). Among other things, in the period of 1998-2015 more than 20 new sunflower processing plants were built, mainly based around the former exporters of sunflower 
seeds; the productive capacities of sunflower seeds processing has increased from 2,6 million tons in 1998 to more than 13 million tons by 2015; the utilization of said capacities has increased from $30 \%$ to $90 \%$ during the same period; the production - from 511 thousand tons to 4,26 million tons by 2015 [Deineko, 2017].

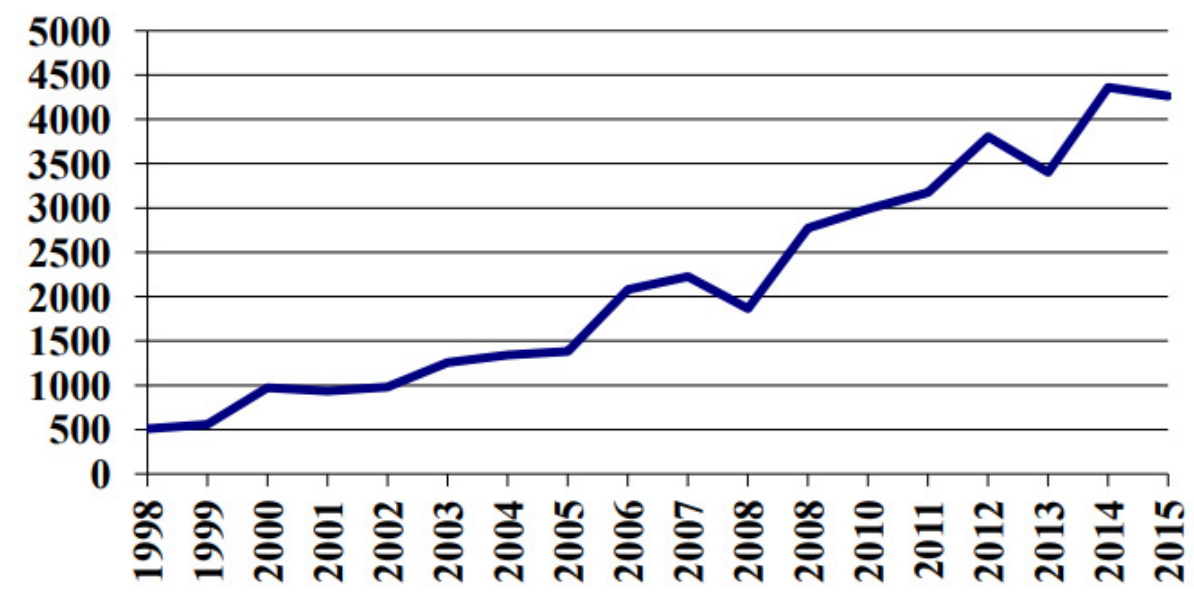

Figure 1. Sunflower oil production in 1998-2015, thousand tons [Deineko, 2017].

Abolishment of the export barriers will not only lead to the outflow of raw materials needed for sunflower oil production, thus ensuring the decrease in exports of processed goods, but also carries substantial risks for the Ukrainian environment, namely through the increase in sunflower cultivation areas, and their expansion to the region that traditionally did not cultivate it. Low technological level of small farms and the lack of government funding that could improve it, as well as the lack of investments due to the unstable socio-political situation, in no small way caused by the Russian occupation of the Autonomous Republic of Crimea and of the areas at the east of Ukraine, will inevitably lead to the extensive approach for cultivating the sunflowers, thus leading to the depletion of soil and, therefore, long-term decrease in soil fertility that will call for the additional costs on fertility recreation and the corresponding increase in the value of the products in future. Unfortunately, with the current integrative processes in force, there are no obvious instruments on how to avert this situation, as the relevant agreements do not stipulate them and those contained in the national legislation are either severely limited or altogether abolished in the trade relations with the European Union - no additional export tariffs may be employed on the relevant export.

Therefore, it is of a high importance to understand how such trade agreements influence the tariff and non-tariff instruments of state regulation, as well as what are the main trends in the area.

Strengthening of the integrative processes is happening by the three interconnected but autonomous ways: globally, through the World Trade Organisation, corresponding multila- 
teral establishment agreement, General Agreement on Tariffs and Trade and complimentary documents; regionally, through the regional multilateral trade agreements that create or expand regional integrative formations, such as the European Union, Eurasian Economic Union, Trans-Pacific Partnership etc.); bilateral trade agreements, mainly aimed at the creation of free trade zones (for example, the Free Trade Agreement between Ukraine and Israel).

First of all, lets explore the influence of the World Trade Organisation. It is currently the biggest integrative formation, containing 164 member-states that create the most of the global goods and services turnover. The main goal of this organisation is to gradually decrease the level of tariff and non-tariff barriers to trade among the member-states, so that the countries with the economies that are yet to fully develop could receive a part in the international trade that could suit their development needs. Nevertheless, despite the declared goal of trade liberalisation, the WTO's mechanisms stipulate the possibility to use some protective instruments, namely in the General Agreement on Tariffs and Trade (1947 and 1994 iterations), Agreement on Subsidies and Countervailing Measures, Agreement on Technical Barriers to Trade, Agreement on Safeguards and several agreements for specific industries, such as the Agreement on Agriculture. In the framework of this paper, import tariffs, technical barriers to trade, sanitary and phytosanitary measures, as well as anti-dumping, compensatory, special and protective measures.

Manipulation of import tariffs is the most common and classic instrument of state regulation in this framework. While, as a rule, when joining to the WTO future member-states oblige themselves to reduce their tariff barriers, resulting into the so-called "bound tariff rates" - the upper limit of tariff rates a state may establish, the WTO rules provide for the possibility to change the obligations assumed by the country when joining this organization, especially if such a right was reserved by said country during the joining. As the impact of tariff rates level per se on the international trade and national economic development is already a highly-scrutinised topic, we will focus on emphasizing the flaws of this instrument - while the level of the actual tariff rates may be lower than that which the country has undertaken to assume upon joining WTO, an increase of tariff rates must be agreed with all interested parties in order to determine sufficient compensation for losses they may endure. In the absence of such consent and/or the corresponding compensations on other tariff lines, not only other states may apply special measures in relation to imports from the country that are provided by the general WTO mechanisms, but they also may file for and receive additional compensation provided for by the Understanding on rules and procedures governing the settlement of disputes that came into 
force on the $15^{\text {th }}$ of April of 1994. It should also be noted that for developed countries, there is a higher degree of coincidence of the bound (maximum within the WTO) tariff rates and the actual tariff rates, while in the developing countries the boudn tariff rates play the role of a "ceiling", and the actual ones are considerably lower than them.

While the WTO has been rather efficient in reaching its goals since its creation in 1995, demonstrating a stable negative dynamics of the actual Most Favoured Nation tariff rates (the main WTO instrument in the field of tariff regulation), having reduced the average tariff rates by more than $46 \%$, and by more than $41 \%$ form the weighted average perspective (what is even more important, generally the weighted average tariff rate is lower than the nominal), if we compare the general trend to the trends in separate industries - those that are traditionally considered "sensitive" - we may observe that the tariff rates are being manipulated there, so to execute state policies, for example - of food security (see Figure 2).

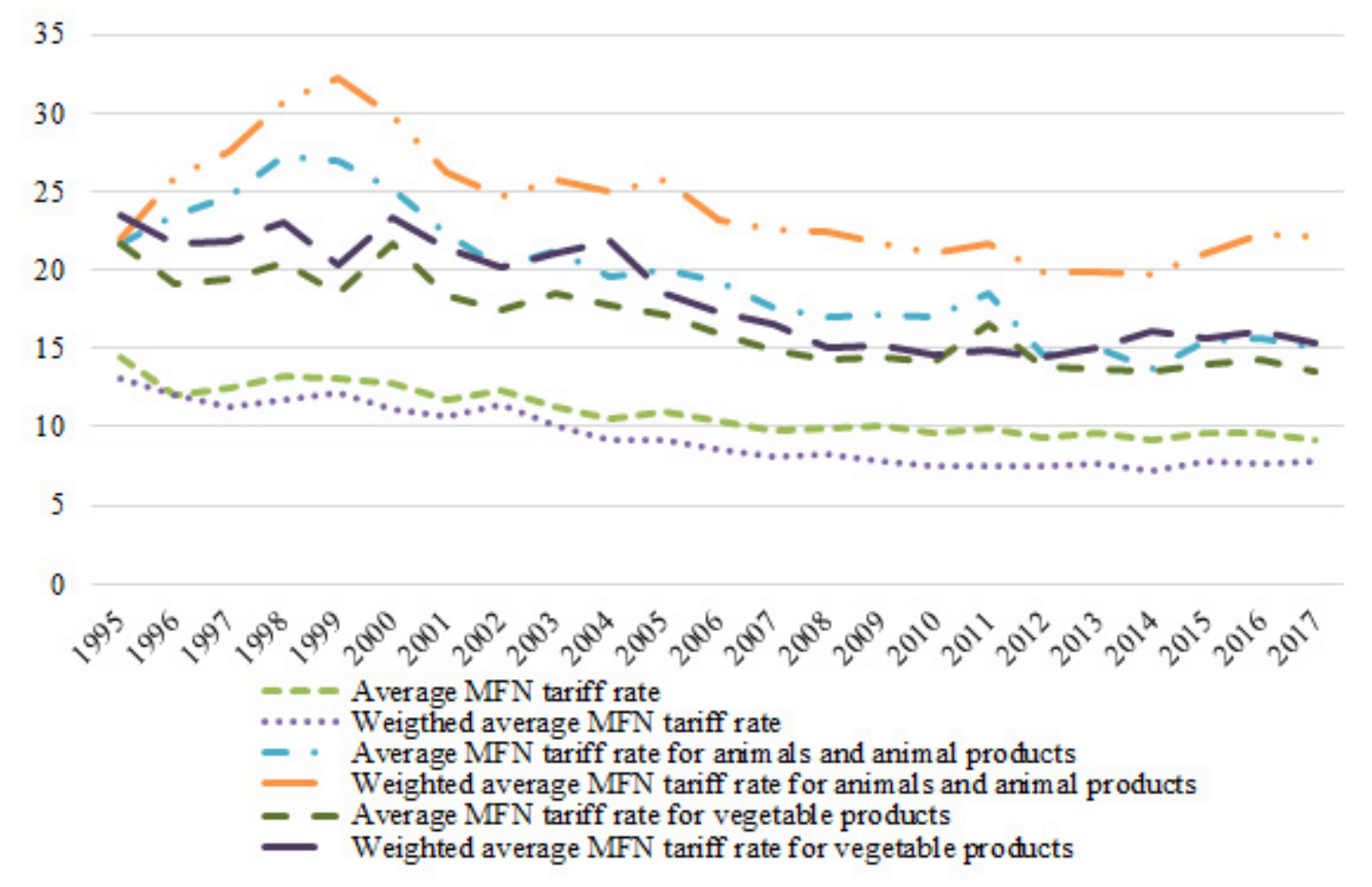

Figure 2. General average MFN tariff rates compared to the average MFN tariff rates on animals, as well as animal and vegetable products after the establishment of the WTO

As it may be observed, in the field of agri-food products not only the average tariff rates are higher as a whole, the weighted average tariff rates are higher than their nominal counterparts, indicating disproportionate and atypical tariff rates for products that are more important for international trade and food security. 
Particularly, as it may be observed on the Figure 2, the weighted average tariff rate is not only abnormally higher than the average tariff rate for vegetable products, but the negative dynamics are slower, as well as less stable. On average the tariff rates decreased by $47 \%$, while on weighted average - only by $35 \%$.

The situation is even more formidable for animals and animal products: while the average tariff rates have decreased by $30,8 \%$, for more important types of animal goods the tariff rates have even increased - by $0,18 \%$.

As evident, a membership even in such a globally encompassing organisation and relative multilateral agreements, while limiting the overall range of the regulative instruments, still leaves some space for realisation of state policies, and maximal approximation of the effective tariff rates to bound ones is one of the most widespread methods in the developed countries. The protective nature of such approximation is further proved by the fact that in developing countries the effective tariff rates are considerably lower than the bound ones, while the latter just play the part of a formal ceiling [Deineko, 2018].

The WTO mechanisms also leave rooms for applying technical barriers to trade, as well as sanitary and phytosanitary restrictions to protect the general consumers, as well as of the national manufacturers, from low-quality products and raw material. Nevertheless, this instrument is still being abused for political goals, like in the case of Russian Federation applying restrictive actions against Ukrainian dairy products from several years before. To somewhat combat such misconduct, the WTO mechanisms stipulate the disputing processes, as mentioned before, but they tend to be long term and they do not, by themselves, halt said restrictive measures.

The WTO mechanisms had also formalised the status of anti-dumping duties at the global level. Currently it is one of the most widespread "emeregecy relief" measure for domestic markets: in the period of 1995-2016 alone the member-states of the WTO have inititated 5286 anti-dumping investigations, with 3405 of them resulting in emposing anti-dumping duties [Deineko and Kushnirenko, 2017]. Generally, the effect of its application is similar to just imposing a higher tariff rate - the competetivness of domestic producers increases, while increasing the price of import consumption for the final consumers, but it has a huge merit over the classical tariff instrument (in the framework of the WTO) of being possible to apply not to a given product in general, but to a given product from a particular country, this keeping other import sources unaffected and negating the negative market deformations.

Compensatory duties are similar in nature, being imposed agaist the products that are being subsidised by an exporting state. In the period of 1995-2016 the WTO member-states 
have initated 445 compensatory investigations, with 240 of them resulting in imposing compensatory duties [Deineko and Kushnirenko, 2017].

While the Most Favoured Nation principle is the cornerstone of the WTO, stipulating that the tariff rates that are being proposed to any member-state should be extended to each and every state, the WTO mechanisms leave place for the possibility for creating integrative formations, the member-states of which may receive special tariff treatment trough bilateral and multilateral regional agreements (see Table 1).

Table 1. Types of integrative economic formations

\begin{tabular}{|c|c|c|c|}
\hline $\begin{array}{c}\text { Free Trade } \\
\text { Area }\end{array}$ & $\begin{array}{c}\text { Customs } \\
\text { Union }\end{array}$ & $\begin{array}{c}\text { Single } \\
\text { Market }\end{array}$ & $\begin{array}{l}\text { Economic } \\
\text { Union }\end{array}$ \\
\hline $\begin{array}{l}\text { an integrative forma- } \\
\text { tion of two or more } \\
\text { customs territories in } \\
\text { which the duties and } \\
\text { other restrictive regu- } \\
\text { lations of commerce } \\
\text { are eliminated on } \\
\text { substantially all the } \\
\text { trade between the } \\
\text { constituent territories } \\
\text { in products originating } \\
\text { in such territories. }\end{array}$ & $\begin{array}{l}\text { an integrative formation that } \\
\text { substitutes separate customs } \\
\text { territories of member-states } \\
\text { by one, joint, while elimina- } \\
\text { ting duties and other restric- } \\
\text { tive regulations of commerce } \\
\text { with respect to substantially } \\
\text { all the trade between the } \\
\text { constituent territories of the } \\
\text { fomation or at least with } \\
\text { respect to substantially all } \\
\text { the trade in products origina- } \\
\text { ting in such territories. }\end{array}$ & $\begin{array}{l}\text { an integrative forma- } \\
\text { tion that substitutes } \\
\text { separate customs } \\
\text { territories of member- } \\
\text {-states by one, joint, } \\
\text { as well as ensures the } \\
\text { free flow of goods } \\
\text { and services, as well } \\
\text { as any factors of } \\
\text { production, such as } \\
\text { capital and labour, } \\
\text { through the borders of } \\
\text { member-states. }\end{array}$ & $\begin{array}{c}\text { a single } \\
\text { market, with } \\
\text { the addition } \\
\text { of the } \\
\text { harmonised } \\
\text { economic } \\
\text { policies, } \\
\text { including } \\
\text { the regu- } \\
\text { lative and } \\
\text { macroeco- } \\
\text { nomic fields. }\end{array}$ \\
\hline
\end{tabular}

Because of that, the number of such agreements was able to increase from 50 in 1990 to 294 in 2019, and almost half of the global trade is happening between the parties of such agreements (see Figure 3).

45

600

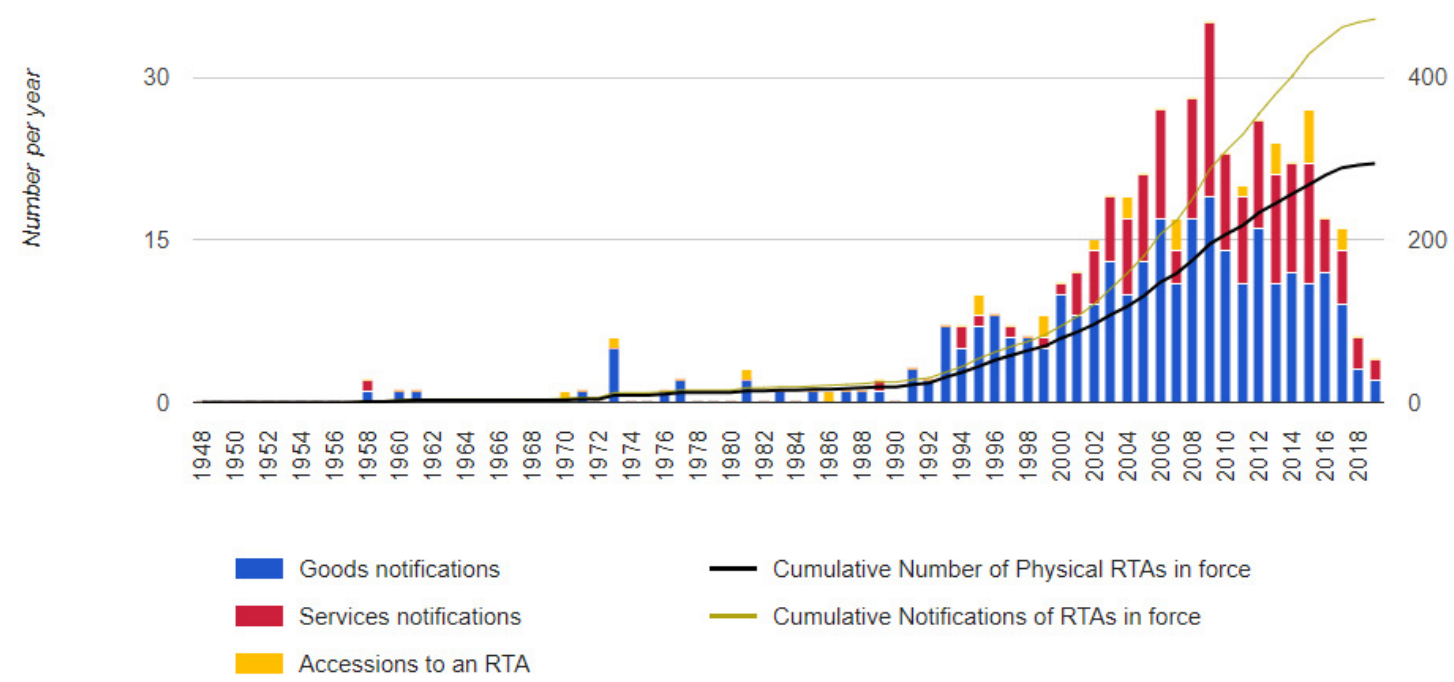

Figure 3. Dynamics of regional (multilateral and bilateral) trade agreements in force (1948-2019) [Regional Trade Agreements Information System n.d.] 
By limiting the number of parties and concentrating on strategic interests, such agreements allow for a deeper regulation in the field of trade and economic integration, than general WTO provisions - while at the beginning they were focused on just decreasing the tariff and technical barriers, but now they tend regulate such things as intellectual property, investment activities, transfer of labour resources, competition, ecological standards and state procurements.

While the exact regulative scope differs from an agreement to an agreement, several clear general and/or notable trends may be observed.

First of all, the central element of such agreements is still the lowering or elimination of tariff barriers among the member-states. Through such agreements they may receive preferential access to the domestic markets of other members, keeping the privileges of lower tariffs from other WTO members. As it may be observed at Figure 4, while the less sensitive products still incur much larger decrease in tariff rates compared to the sensitive ones, and the latter are not usually subjected to any substantial change of rates, being regulated by a mechanism of tariff quota instead. This mechanism allows for attraction of desired products to a given domestic markets without violating the security of domestic producers.

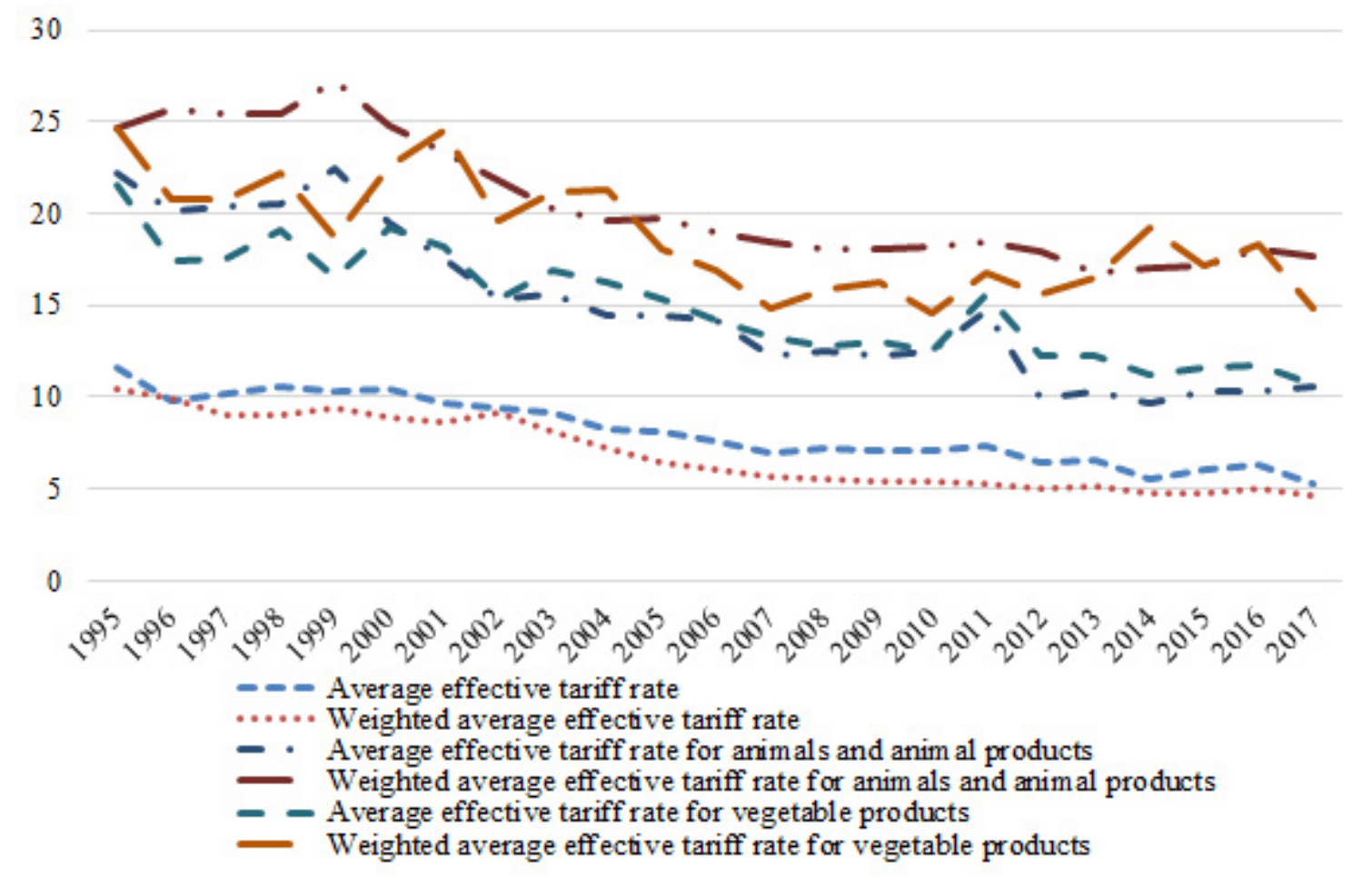

Figure 4. General average tariff rates compared to the average tariff rates on animals, as well as animal and vegetable products after the establishment of the WTO

In the non-tariff field, it has to be noted that the last multilateral and bilateral agreements do not concentrate on regulating the barriers per se, but more on ensuring the proper communication 
and coordination among the member states on the relevant problems, thus indirectly proving that non-tariff barriers are more an instrument of politics than of the economic policy.

It has also to be highlighted that such agreements generally recognise all the rights and obligations established by the WTO regarding the restrictions on exports and allow for their temporary execution in exceptional circumstances; nevertheless, some of them (like in the case of the free trade agreements between the United Mexican States and the Plurinational State of Bolivia and between the United Mexican States and the Republic of Columbia) limit the types of products that may be affected, as well as the time scope of such actions, others still - even prohibit the export restrictions as a whole, without exceptions (like in the Agreement establishing an association between the European Community and its member states and the Republic of Chile)

Generally, regional trade agreements do not contain provisions on the domestic support of the agri-food sector, as any restrictions on such support would benefit not only the parties a relevant agreement, but all of their trade partners, thus negating the primary reasons to enter such an agreement.

\section{Bibliography:}

1. Дейнеко, О. (2016) Ризики зниження експортного мита на насіння соняшника у контексті угоди про асоціацію між Україною та ЄС, Економічний вісник університету, 29/2

Deineko, O. (2016) Ryzyky znyzhennia eksportnoho myta na nasinnia soniashnyka u konteksti uhody pro asotsiatsiiu mizh Ukrainoiu ta YeS, Ekonomichnyi visnyk universytetu, 29/2

2. Дейнеко, О. (2018) Вплив сучасних правил міжнародної торгівлі на митне регулювання агропродовольчого ринку,

Вісник Інституту економіки та прогнозування

Deineko, O. (2018) Vplyv suchasnykh pravyl mizhnarodnoi torhivli na mytne rehuliuvannia ahroprodovolchoho rynku, Visnyk Instytutu ekonomiky ta prohnozuvannia

3. Deineko O. (2017) Tariff And Non-Tariff Regulation Of An Agri-Food Market In Ensuring Sustainable Development: International Experience And Ukrainian Practice, MIND JOURNAL, Vol. 1, №4

4. Олефір, В. (2014) Розвиток агропродовольчих секторів Болгарії, Польщі та Румунії в умовах поглиблення євроінтеграці, Економіст, № 12. Olefir, V. (2014) Rozvytok ahroprodovolchykh sektoriv Bolharii, Polshchi ta Rumunii v umovakh pohlyblennia yevrointehratsi, Ekonomist, №12. 
5. Осташко, Т. (2012) Перспективи та ризики у торгівлі сільськогосподарськими товарами з країнами єдиного економічного простору,

Економіка і прогнозування, № 1.

Ostashko, T. (2012) Perspektyvy ta ryzyky u torhivli silskohospodarskymy tovaramy z krainamy yedynoho ekonomichnoho prostoru, Ekonomika i prohnozuvannia.,. № 1.

6. Дейнеко, О. та Кушніренко, О. (2017) Система інструментів для захисту вітчизняних виробників в рамках дії торговельних угод, Управління економічними процесами: сучасні реалії і виклики. Deineko, O. ta Kushnirenko, O. (2017) Systema instrumentiv dlia zakhystu vitchyznianykh vyrobnykiv v ramkakh dii torhovelnykh uhod, Upravlinnia ekonomichnymy protsesamy: suchasni realii i vyklyky.

7. World Integrated Trade Solution. URL: https://wits.worldbank.org/

8. Regional Trade Agreements Information System. URL: http://rtais.wto.org/UI/ PublicMaintainRTAHome.aspx 